\title{
A Constituency-based Support Model for Delivering Information Services
}

\author{
Christopher D. Barth and Janet R. Cottrell
}

\begin{abstract}
An information services organization based on individual constituent groups, instead of defined physical collections and technologies, encourages a broader, more effective, and innovative use of varying information and technology services for academic libraries. Such a model also provides more focused and clearly defined positions and procedures to ensure high-quality support to all constituents.
\end{abstract}

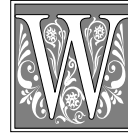

hom do librarians serve? Whom should they serve? The standard answer is the patrons, be they taxpayers, tuition-payers, or fellow employees. Yet, the management structures of most academic libraries usually choose a different constituency to base their structure on: their resource materials. In this organizational model, staff are organized around books, audiovisual materials, technology resources, and so on, rather than around the users of these materials. Such structures reinforce a compartmentalized view of information resources and technology among our patrons, and although the patrons receive service through these channels, the focus of the organization remains inward on its own collections.

A constituency-based support model integrated within the organizational structure of the library allows professionals to better understand and develop skills to serve their patrons, and facilitates the comprehensive nature of tech- nology within library services. This support model encourages consistent reference support for all information sources, from books to microforms to electronic data warehouses to computer hardware, from one individual or service desk. This results in a demystification of the range of information services and information delivery mechanisms for both patrons and librarians and promotes the development of skills to better harness the forces of technology within library services. However, implementation of this model requires some understanding of the differences between traditional information technology (IT) support and library services support, as well as the ways in which models for these individual support roles have developed.

\section{Support Models for Computing and Library Services}

The challenges of providing effective IT support have been well defined. Michael J. Yohe identified strategies useful in controlling expectations, reducing work,

Christopher D. Barth is a Librarian and Technology Consultant in Library and Information Services at Kenyon College; e-mail: barth@kenyon.edu. Janet R. Cottrell is Director of Information Access in Library and Information Services at Kenyon College; e-mail: cottrellj@kenyon.edu. 
and promoting self-sufficiency. He also emphasized collaboration, redistribution of responsibility, and increased communication as effective approaches. ${ }^{1}$ Polley A. McClure, John W. Smith, and Tobey D. Sitko further described the processes by which centralized computing support organizations are overwhelmed by demand and noted that central IT organizations can become scapegoats because they present a big, easy target. ${ }^{2}$ McClure and her coauthors proposed a support mechanism focused on customer needs; in particular, they advocated educating campus constituencies and engaging users in decisions that affect them.

Several articles in the literature describe alternative computer support models. Richard M. Kesner described a series of service delivery models developed at Babson College, including a help desk and dispatch support, Technology Specialists Residential Technology Associates programs, as well as dedicated service/support assignments. ${ }^{3}$ Andrea Nixon and Paula Lackie described Carleton College's discipline-focused computing support structure, in which technical support staff focus on supporting the IT-related pedagogical needs of the faculty in their division. ${ }^{4}$ On a larger scale, Mark Donovan and Scott Macklin described a scaleable, client-centered support model for supporting technology in teaching at the University of Washington. ${ }^{5}$ Sue Ellen Breedon, Ellen Ramsey, Susan Evans, Gene Roche, and Michele Valliere described two different models: one at the University of Virginia, where individual departments hire, fund, and supervise technical staff ; and the other at the College of William and Mary, where a central IT unit funds liaisons who reside in the departments they serve. $^{6}$

Academic libraries frequently employ a liaison model, so their models tend to be more familiar. These models are typically faculty oriented; library liaisons support specific faculty in their library research needs, work with faculty to develop discipline-based collections, and provide bibliographic instruction for students. As an example, Zheng Ye (Lan) Yang provided a useful list of liaison activities, along with a model for assessing faculty perceptions of a liaison program. ${ }^{7}$ For a slightly different slant, Karen E. Greever, a technical services librarian at Kenyon College, described the benefits of taking on public services, particularly reference, in addition to her behind-the-scenes duties. ${ }^{8}$ This type of cross-focus began to build bridges with constituents, notably faculty, to better serve the user by bringing a more holistic approach to service through focusing on the patrons rather than the collections.

Merged library and computing service organizations vary greatly in their structure and focus. In many cases, the support mechanisms for library services and for computing services are in effect separate mechanisms; in a few cases, more integrated service organizations result. Arnold Hirshon supplied organizational charts for several schools in his 1998 planning guide. ${ }^{9}$ More recently, Larry Hardesty described theoretical and historical approaches to merged library and computing organizations, along with case studies. Both of these sources illustrate other possible models. ${ }^{10}$

Of particular note is Chris Ferguson's article advocating a unified service model that integrates reference and information services with technology support. ${ }^{11}$ In addition to reviewing the reengineering necessary to achieve such a model, Ferguson pointed to three existing, and quite different, models (California Lutheran University, The University of Southern California, and UCLA) that provide integrated services. He also noted that the variety of working models reflects the variety of institutions seeking change; different schools will find different solutions.

\section{Kenyon's Constituency Model}

A little more than three years ago, Kenyon College implemented a merged library and computing services structure. To address the growing need for 
campuswide information services support, Kenyon developed a unique constituency-based support model. In this model, students, faculty, and administrators are viewed as separate constituencies, with specific support strategies for each.

Although information support for students, faculty, and administrators often overlaps, primary support for each group is assumed by a specific group of staff that provides both library and computing support for that constituency. The director of each department also assumes

\section{Within each administrative division, a computer records supervisor position has responsibility for the operation of the system processes and maintains the integrity of the data for the division.}

a special role-that of advocate for the department's constituency within the service organization. This advocacy role does not require the director to assert his or her constituency's demands over those of the others, merely to ensure that they are understood and represented, then met insofar as possible.

\section{Support for the Faculty Constituency}

To meet the specialized needs of faculty, Kenyon has developed a unique job category - the library and technology consultant, or LTC. The LTCs provide both library and computing support to faculty in specific, assigned academic departments, but their support cuts across the spectrum of information resources and technology needs. LTCs work closely with faculty to perform collection development, teach effective use of software and the library, and promote innovative applications of information literacy in the liberal arts setting. An LTC at Kenyon may be found:

- participating in reference and technology consulting services;

- $\quad$ aiding in the identification, implementation, and use of both traditional and electronic information resources;
- participating in the academic department liaison program as a subject specialist and a technology specialist;

- providing personalized support for faculty using computers, software, and instructional technology;

- participating in various instruction programs, including basic library usage skills, advanced library research and electronic search skills, software applications, and instructional technologies;

- providing frontline technical hardware and software support for computer equipment in the academic division;

- designing and implementing new technology-based facilities along with faculty to support new initiatives in the curriculum.

The breadth of this support model ensures that each LTC has the opportunity to understand departmental pedagogical, research, and technology goals, as well as to form personal connections and long-term multifunctional relationships with faculty. Such relationships allow for and encourage more complex and innovative discussions on the integration of library and technology services within the pedagogy of individual faculty, as one liaison colleague provides combined library and technology services. The many and varied responsibilities of the support relationship typify the liberal arts experience- and reflect the organization's response to meeting diverse needs with limited resources.

Individual LTCs develop particular areas of expertise regarding both library and technology services, and the model relies on networking among liaisons to provide specialized consulting services across the division. This allows the development of specialists within the generalist support model.

\section{Support for the Administrative Constitu- ency}

Kenyon's administrative computing support also is tailored to meet the requirements of the administrative constituency. Information analysts support specific administrative divisions. Thus, in addition 
to technical skills, the analysts must understand the unique operational requirements of their division in order to provide appropriate support. Within each administrative division, a computer records supervisor position has responsibility for the operation of the system processes and maintains the integrity of the data for the division. This position also serves as the first line of support for other personnel in the division. In addition, it serves as liaison to the administrative computing staff. This partnership provides system support to each administrative office. This support is crucial because Kenyon is migrating all administrative systems from a text-based host system platform to client/server workstation platforms using relational database tools and Web products. Effective partnerships between the information analysts and the computer records supervisors have been a key success factor in this migration.

Not surprisingly, administrative units at Kenyon request little in the way of library support. In the traditional sense, their needs bear little resemblance to those of the faculty, except perhaps in terms of Web design and organization. However, the professional skills of librarians in areas of information organization and delivery are important to the effective dissemination of information through these administrative systems, and Kenyon is integrating some of these skills brought by information professionals into administrative systems. In addition, Kenyon is in the process of developing an innovative new program to support institutional information by combining the expertise of archivists, librarians, and digital media specialists with traditional computing support in order to retain, preserve, organize, and provide access to the wide range of institutional records generated at any college or university. The technical expertise of Kenyon's professional information services staff makes this type of cross-cooperation and integration particularly appropriate and successful in its implementation.

\section{Support for the Student Constituency}

To meet the needs of students, primary responsibility for all major service areas of core library and technology functions resides within one department. Thus, traditional library departments focusing on access to collections, such as the library reference desk, audiovisual department, circulation, and interlibrary loan are teamed with public-use campus computing labs, the technology HelpLine, and computing areas within the library/technology center and managed in one department. Residential computing services are comanaged along with Kenyon's core infrastructure support team. Student government representatives meet regularly with the director of this group to exchange ideas. Both formal and informal student input is taken seriously; such input is partly responsible for new group study and quiet areas, the installation of network connections for laptop use, and the implementation of a pilot wireless networking project within the library facility.

In addition to traditional paraprofessional support staff, Kenyon also involves the aforementioned LTCs as important links in providing student support. All LTCs currently hold professional library science degrees and work regular reference shifts. Because they also bring advanced technology skills to their work, they are able to answer a wide variety of questions ranging from traditional research queries to sophisticated technological problems. This ability to respond to the full spectrum of information problem-solving issues is vital because workstations throughout Kenyon's library facility, including the reference area, contain a full load of productivity software in addition to library research tools. Students working on course projects in the library's reference area generate multifaceted and difficult reference and technical support questions, and can receive support through the easily identifiable reference librarian. Providing this full spectrum of support for all steps in creating a project, from find- 


\section{A Constituency-based Support Model for Delivering Information Services 51}

ing appropriate information sources to producing a final product, is an important aspect of student support.

For technology questions from outside the vicinity or scope of the reference desk, the traditional computer HelpLine is available. This frontline student-staffed support area providing phone, e-mail, and walkin technology support for all students, faculty, and staff is managed by an LTC. Having an LTC in charge of this service is a deliberate decision in order to infuse the theoretical information management skills of a professional librarian into a traditional IT support desk to better understand and serve users. This has resulted in better and more accessible documentation for both end users and other support staff. An extension of this library information technology intersection is a proposal to implement traditional HelpLine problem-tracking software at the library reference desk. By tracking certain kinds of questions and problems (without breaching the confidentiality of the reference environment), staff hope to better address repeated or ongoing questions.

A final, and less tangible, benefit of an integrated support environment for students is the opportunity for students themselves to receive a high level of cross-training in both traditional library research methods and troubleshooting difficult technical problems. The integration of library and information technology services becomes more seamless for students, whether they use the library regularly for academic study or work as an LTC assistant or a HelpLine employee. These skills will only serve to benefit students as they prepare for employment in an increasingly technologically dependent world.

\section{Conclusion}

Each constituency in an academic library brings different and often competing needs to the table. Given finite resources, many colleges and universities face increasing difficulty in balancing those needs. Yet, making sure that needs are met is an essential purpose-and often a prerequisite for survival —of an effective information technology services organization.

Academic libraries enjoy the luxury of having a clearly defined patron base: distinct constituencies of students, faculty, and administrators. The experience at Kenyon indicates that an information services support division charged with supporting these different groups can most effectively meet that challenge by installing an organizational structure that matches its constituents. By reversing a focus on serving collections and turning toward information as a holistic tool spanning formats and defined collections, patron services are enhanced and the library can encourage the use and synthesis of information in new ways for its patrons.

\section{Notes}

1. J. Michael Yohe, "Information Technology Support Services: Crisis or Opportunity?" CAUSE/EFFECT 19 (fall 1996): 6-13.

2. Polley A. McClure, John W. Smith, and Toby D. Sitko, The Crisis in Information Technology Support: Has Our Current Model Reached Its Limit? CAUSE Professional Paper \#16 (Boulder, Colo.: CAUSE, 1997).

3. Richard M. Kesner, "Developing an Information Technology Support Model for Higher Education," CAUSE/EFFECT 20 (summer 1997): 24-30.

4. Andrea Nixon and Paula Lackie, "Discipline-focused Technology Support Fosters Curriculum Innovation," CAUSE/EFFECT 22 (fall 1999): 33-36.

5. Mark Donovan and Scott Macklin, “One Size Doesn't Fit All: Designing Scaleable, Client-centered Support for Technology in Teaching" (paper presented at CAUSE98: The Networked Academy, Seattle, Wash., Dec. 8-11, 1998). Available online from <http:// www.educause.edu/ir/library/html/cnc9846/cnc9846.html>.

6. Sue Ellen Breeden, Ellen Ramsey, Susan Evans, Gene Roche, and Michele Valliere, "One Size Does Not Fit All: Models for Support and Training Partnerships in Virginia" (paper pre- 
sented at Educause 2000, Nashville, Tenn., Oct 10-13, 2000). Available online from http:// www.educause.edu/ir/library/pdf/EDU0002.pdf.

7. Zheng Ye (Lan) Yang, “University Faculty's Perception of a Library Liaison Program: A Case Study," Journal of Academic Librarianship 26 (Mar. 2000): 124-28.

8. Karen E. Greever, "Building Bridges: Moving from the Back Room to the Front Line," Catholic Library World 70 (Sept. 1999): 23-26.

9. Arnold Hirshon, Integrating Computing and Library Services: An Administrative Planning and Implementation Guide for Information Resources, CAUSE Professional Paper Series, \#18 (Boulder, Colo.: CAUSE, 1998).

10. Larry Hardesty, Ed., Books, Bytes, and Bridges: Libraries and Computer Centers in Academic Institutions (Chicago and London: ALA, 2000).

11. Chris Ferguson, "'Shaking the Conceptual Foundations,' Too: Integrating Research and Technology Support for the Next Generation of Information Service," College E Research Libraries 61 (July 2000): 300-11. 